\title{
Effect of different management on quality and value production of pure beech stands in Slovakia
}

\author{
Igor Štefančík ${ }^{1}$, Michal Bošel'a*1,2, Rudolf Petráš ${ }^{1}$ \\ ${ }^{1}$ National Forest Centre - Forest Research Institute Zvolen, T. G. Masaryka 2175/22, SK - 96092 Zvolen, Slovak Republic \\ ${ }^{2}$ Technical University in Zvolen, Faculty of Forestry, T. G. Masaryka 24, SK- 96053 Zvolen, Slovak Republic
}

\begin{abstract}
Value production is one of the most important information for comparing different management strategies in forestry. Although the value production of forest stands is affected by various factors (stem and assortment quality, stem dimension, stem injury, price of assortments), thinning can be considered as one of the most important one. This paper aims at the evaluation of qualitative and value production in homogeneous beech stands, which were managed by two different thinning types for period of 45 to 55 years: (i) - heavy thinning from below (C grade according to the German forest research institutes released in 1902) and (ii) - Štefančík's free-crown thinning. The third variant was control (iii) - subplot with no interventions. Silvicultural quality characteristics of the lower half of the stem were assessed using a 4-class scale (A - the best quality, D - the worst quality). Assortment structure (commercial quality) was estimated for each stem by an assortment model developed in the past. Nearly 3,000 individual trees aged from 83 to 105 years from 23 subplots established across the Slovakia territory were assessed. The highest volume of the best silvicultural quality of stems (A class) has been reached in forests where Štefančík's free-crown thinning was applied $(57-85 \%)$ while the lowest $(22-56 \%)$ on subplots with no management. The proportion of two best commercial quality assortments (I + II) was highest in forests managed by heavy thinning from below (21 - 29\%) and the lowest when no treatment was applied $(7-19 \%)$. The highest value production (expressed in $€$ ha $^{-1}$ ) was reached in the forests treated by free-crown thinning. Results suggested the overall positive impact of thinning on the increase of value production in beech forests. Particularly, the free-crown thinning focusing on selection of best quality trees should be preferred as it leads, besides its sufficient value production, to a higher vertical differentiation of the beech forests.
\end{abstract}

Key words: pure beech stands; thinnings; stem quality; assortment structure; value production

Editor: Jiří Novák

\section{Introduction}

Qualitative and value production of forest stands are key aspects particularly connected with broad-leaved tree species (oak and beech). Recently, it has become particularly important because the financial evaluation (monetization) of thinnings realized during the whole tending period together with the assessment of mature stands entered a crucial role in assessing the effectiveness of performed tending. Quality of standing stems in forests may be assessed by the quality of stem by external growing traits such as stem straightness, number and size of knots, spiral grain, stem damage etc. (Štefančík 1974) or by the commercial timber quality, assessed by the use of assortment model (Petráš 1992).

Growth and development is affected by the site conditions characteristics (Vacek \& Hejcman 2012; Vacek et al. 2014; Vladovič et al. 2014), stand conditions (Bartoš \& Souček 2010; Jullien et al. 2013; Merganič et al. 2013), genetic properties and characteristics (Ducros et al. 1988; Hansen et al. 2003; Gömöry \& Paule 2011; Gömöry et al. 2013), including an appropriate provenance (Novotný et al. 2015) and the way of forest management (Štefančík 1974, 2015; Mlinsek \& Bakker 1990; Hein et al. 2007; Poleno \& Vacek et al. 2009; Vacek et al. 2015).

Many authors found a positive impact of the longterm tending on the timber quality of beech stands (Šebík 1970; Štefančík 1974; Kató \& Mülder 1983; Korpel' 1988; Mlinsek \& Bakker 1990). Particularly, selective thinnings (Šebík \& Polák 1990; Štefančík et al. 1996; Cameron 2002) by the target trees method (Skovsgaard et al. 2006; Hein et al. 2007; Štefančík \& Bošela 2014; Štefančík 2015) are the most appropriate. In addition, 
thinning increases the quality of beech timber (Keller et al. 1976; Ferrand 1982; Cameron 2002; Poljanec \& Kadunc 2013).

Value production of beech stands is significantly reduced by a false heart and/or by wood rot (Knoke \& Wenderoth 2001; Knoke 2003; Krpan et al. 2006), or by the occurrence of knots on the stem (Richter 2007). Despite the extensive research on beech stands from various aspects, there is a lack of knowledge about the value production of beech in pure (Sedmák \& Hladík 2002; Utschig \& Küsters 2003) or mixed stands (Petráš et al. 2015). In particular, it is questionable whether different management can significantly affect (increase) value production of beech stands in comparison to stands without any interventions.

Presented study focuses on the assessment of stem quality and value of assortments in pure beech stands that were exposed to two different thinning methods for the last $45-55$ years. The hypothesis that stands with different thinning methods will produce different value production expressed by only last assessment of stem quality and assortment value and that subplots with no interventions are expected with the lowest value production was tested.

\section{Materials and methods}

\subsection{Establishment of long-term research plots}

Twenty three subplots at seven localities (plots) across Slovakia were established by the Prof. Dr. Ladislav Štefančík during 1959-1969 period in homogeneous, even-aged naturally regenerated beech forests in Slovakia (Fig. 1). At the time of their establishment, the forests were in a growth stage from small pole to pole timber. Table 1 shows basic site characteristics of the plots.

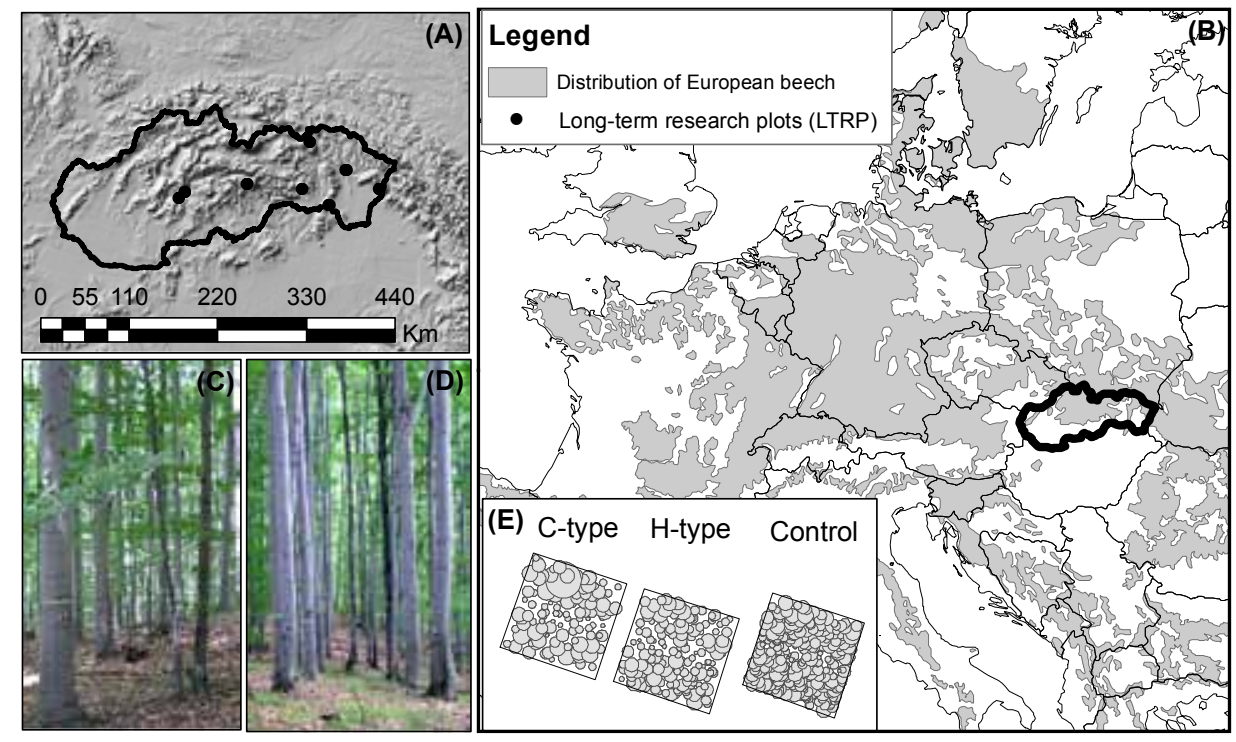

Fig. 1 (a) The distribution of the study localities across the Western Carpathians (Slovakia) used in this study, (b) the present distribution of European beech (source: Euforgen, 2015) with highlighted boarder of Slovakia, (c) beech forest in 2015 after applying the free crown thinning (thinning from above aimed at supporting the selected best-quality trees - all suppressed trees are subject to natural mortality only), (d) beech forest in 2015 after applying the heavy thinning from below (all suppressed and sub-dominant trees were removed), and (e) an example of placement of the research subplots in a locality including the spatial distribution of trees mesured in 2015 - the circle size represents crown projection area.

Table 1. Site characteristics for the 23 permanent research plots in European beech (Fagus sylvatica L.) included in the analysis.

\begin{tabular}{|c|c|c|c|c|c|c|c|c|c|}
\hline \multirow[b]{2}{*}{ Plot/subplot } & \multirow{2}{*}{$\begin{array}{c}\text { Number of } \\
\text { inventory cycles }\end{array}$} & \multirow{2}{*}{$\begin{array}{c}\text { First-last } \\
\text { measurement }\end{array}$} & \multirow{2}{*}{$\begin{array}{c}\text { Age span } \\
\text { [years] }\end{array}$} & \multicolumn{2}{|c|}{ Geographic position } & \multirow{2}{*}{$\begin{array}{c}\text { Elevation } \\
\text { a.s. l. } \\
{[\mathrm{m}]}\end{array}$} & \multirow{2}{*}{$\begin{array}{c}\text { Mean annual } \\
\text { temperature } \\
\left.{ }^{\circ} \mathrm{C}\right]\end{array}$} & \multirow{2}{*}{$\begin{array}{c}\text { Mean annual } \\
\text { precipitation } \\
{[\mathrm{mm}]}\end{array}$} & \multirow[b]{2}{*}{ Soil unit } \\
\hline & & & & E-longitude & N-latitude & & & & \\
\hline Jalna/C,H,0 & 12 & 1959-2012 & $36-89$ & 48.55 & 18.95 & 610 & 6.2 & 800 & Eutric Cambisol \\
\hline Konus/C,H,0 & 12 & 1961-2014 & $30-83$ & 48.78 & 22.30 & 510 & 6.5 & 900 & Eutric Cambisol \\
\hline $\mathrm{Kalsa} / \mathrm{C}, \mathrm{H}, 0$ & 12 & 1961-2014 & $37-90$ & \multirow{2}{*}{48.58} & \multirow{2}{*}{21.48} & 520 & 6.0 & 790 & \multirow[t]{2}{*}{ Stagni-Eutric Cambisol } \\
\hline Kalsa/H2 & 10 & 1969-2014 & $45-90$ & & & 520 & 6.0 & 790 & \\
\hline Zalobin/C,H,0 & 12 & $1962-2015$ & $39-92$ & 48.98 & 21.74 & 250 & 7.9 & 660 & Stagni-Eutric Cambisol \\
\hline Zlata Idka/C,H,0 & 12 & $1960-2013$ & $40-93$ & 48.74 & 21.01 & 700 & 6.7 & 780 & Haplic Cambisol \\
\hline Ciganka/C,H,H2,0 & 10 & 1967-2012 & $60-105$ & 48.76 & 20.09 & 560 & 5.5 & 918 & (Dystric) \\
\hline Lukov/H,0 & 11 & 1962-2011 & $45-94$ & \multirow{2}{*}{49.28} & \multirow{2}{*}{21.10} & 550 & 5.5 & 690 & Haplic Cambisol \\
\hline Lukov/C & 10 & 1966-2011 & $49-94$ & & & 550 & 5.5 & 690 & (Dystric) \\
\hline
\end{tabular}

Comment: C-heavy thinning from below (Cgrade according to German forestry research institutes from 1902); $\mathrm{H}$-the free crown thinning according to Stefancik (1984) principles, thinning interval of 4 or 5 years; $\mathrm{H} 2$ - the free crown thinning according to Štefančí (1984) principles, thinning interval of 10 years; 0 - control plot (no thinning). 
No systematic interventions were performed in the forests until the establishmet of the plots. If there was some intervention, it was of the slight intensity only removing the suppressed trees - so-called wanderingselective felling (Štefančík 1974).

Each plot comprised of 3 to 5 subplots (mostly three), which were arranged next to each other (along the contour line), and separated from each other by a $15 \mathrm{~m}$ wide (the minimum width) isolation belt. The area of each subplot was 0.25 ha $(50 \times 50 \mathrm{~m})$, with the exception for the plot Zalobin with the size of 0.20 ha $(40 \times 50 \mathrm{~m})$. A $10 \mathrm{~m}$ wide transect, where heights of the all trees were measured, was established and evidenced through the center of each subplot.

All living trees with the diameter $\mathrm{DBH} \geq 3.6 \mathrm{~cm}$ and trees which reached this threshold during the measurement period were fixed and numbered. One subplot (specified as 0) in each plot (locality) was left unmanaged as a control plot.

\subsection{Field works}

The following thinning types were applied on the subplots within each plot:

a) Heavy thinning from below (Cgrade according to the German forest research institutes released in 1902) (here recognized as C). All suppressed trees without tendency to support the target trees have been removed. The thinning intensity on this subplots ranged from 37 to $46 \%$ out of basal area total production. Thinning interval was the same as for subplot $\mathrm{H}$.

a) The free crown thinning (thinning from above) with a 5-year (marked as $\mathrm{H}$ ) or 10-year thinning interval (marked as H2) using the principles defined by Štefančík $(1974,1984)$. This thinning method focuses on identifying and supporting the best quality trees growing in the crown level of the stand (target trees). Thinning intensity for this method of thinning ranged from $35 \%$ to $48 \%$ out of basal area production. At first, 4-year thinning interval was used between the first and second and/or second and third intervention on all subplots (except for subplots H2). Later, it was a 5-year interval on the all subplots or 10-year interval (on subplots $\mathrm{H} 2$ only).

In addition to standard biometric measurements, trees were classified into the $1-5$ tree vertical classes (using Kraft classification system). The quality traits of the bottom half of stem were assessed according to the following classification:

A - Straight, non-twisted stem, centric, without shape deformations and knots; suitable for sliced veneer production;

B - Stem with minor technical defects with solid and loose knots up to $4 \mathrm{~cm}$ (1-2 pieces per meter);

C-Stem with large technical defects, greater curvature, and twisted growth up to $4 \%$, solid knots without limita- tion; suitable especially for lower quality saw logs or pulp; D - Stem inferior to the class C, with the extensive rot, and only suitable as fuelwood.

\subsection{Data processing}

The analysis includes only the last inventory on the subplots in order to investigate the long-term effect (45 to 55 years) of the different thinning types on qualitative and value timber production. In total, 2,973 trees were assessed. First, the shares of A - D stem quality classes were defined for each subplot. Assortment structure was estimated by national assortment model (Petráš 1992), which gives the assortments percentage in dependence on the tree diameter (DBH), the stem quality, the stem damage and the stand age. Stem damage was not assessed. We assumed no stem injuries. Therefore the results are not real only theoretical.

Individual assortments represent log classes based on log quality and its diameter. Quality classes of logs are mainly characterized by their intended purpose:

I sliced veneers, special sporting and technical goods,

II peeled veneers, sporting goods,

III (A, B) saw logs (IIIA-better quality, IIIB - worse quality),

V pulpwood; chemical and mechanical processing for pulpwood and agglomerated boards production,

VI fuelwood.

I - IIIB classes defined in the assortment tables model are also separated into $1-6+$ diameter classes. $(1-16$ to $19 \mathrm{~cm} ; 2-20$ to $29 \mathrm{~cm} ; 3-30$ to $39 \mathrm{~cm} ; 4-40$ to $49 \mathrm{~cm} ; 5-50$ to $59 \mathrm{~cm} ; 6+$ more than $60 \mathrm{~cm}$ ).

The estimated assortment value was calculated for each tree as the product of assortments volume and timber prices by $\log$ quality and diameter classes. Timber prices were taken from the state enterprise Forests of the Slovak Republic, Assortment price list published in 2013 (Table 2).

Table 2. Assortments prices $\left(€ \mathrm{~m}^{-3}\right)$ by log quality and diameter classes.

\begin{tabular}{|c|c|c|c|c|c|c|}
\hline \multirow{2}{*}{ Diameter clas } & \multicolumn{6}{|c|}{ Quality class } \\
\hline & L & III & IIA & IIIB & $\mathrm{V}$ & $\mathrm{VL}$ \\
\hline 1 & & & 51.5 & 50.5 & & \\
\hline 2 & & 54.0 & 52.5 & 51.5 & & \\
\hline 3 & & 103.0 & 69.5 & 57.5 & 43.0 & 44.0 \\
\hline 4 & 201.0 & 108.0 & 71.5 & 59.5 & & \\
\hline 5 & 231.0 & 113.0 & 71.5 & 59.5 & & \\
\hline $6+$ & 271.0 & 113.0 & 71.5 & 59.5 & & \\
\hline
\end{tabular}




\subsection{Statistical analyses}

ANOVA was applied to test for the effects of thinning type on the proportion of the highest-quality stems, proportion of I+II and IIIA quality assortments as well as to test the effect on financial return per hectare and per cubic meter. The Bonferroni correction was used to counteract the problem of multiple comparisons. Simple linear and polynomial regression was used to investigate the effects of mean stand diameter, as a characterstic representing forest development, on the proportion of the highestquality stems and potential financial return under different thinning type.

\section{Results}

\subsection{Stem quality}

The highest proportion of the best Aquality stems (Fig. 2) was reached when applying the free crown thinning $(H)$.
It varied from 59 to $85 \%$. On the subplots with heavy thinning from below (C), the proportion of the best quality stems varied in the range of $48-82 \%$. However, the proportion was not found to be significantly different from the previous. The lowest proportion of the best quality stems (22-56\%) was observed in the unmanaged forests (0) (Štefančík 2015).

\subsection{Assortment structure}

The highest proportion $(21-28 \%)$ of the best quality assortments (I+II) was found on the subplots where the thinning from below was applied. The lowest proportion of such quality trees $(6-19 \%)$ was observed on control subplots as well as in forests managed by free-crown thinning (4-22\%). Similarly, the highest proportion of IIIA quality stems was reached in forests treated by heavy thinning from below. On the contrary, the free-crown thinning provided the lowest proportion of such stems.

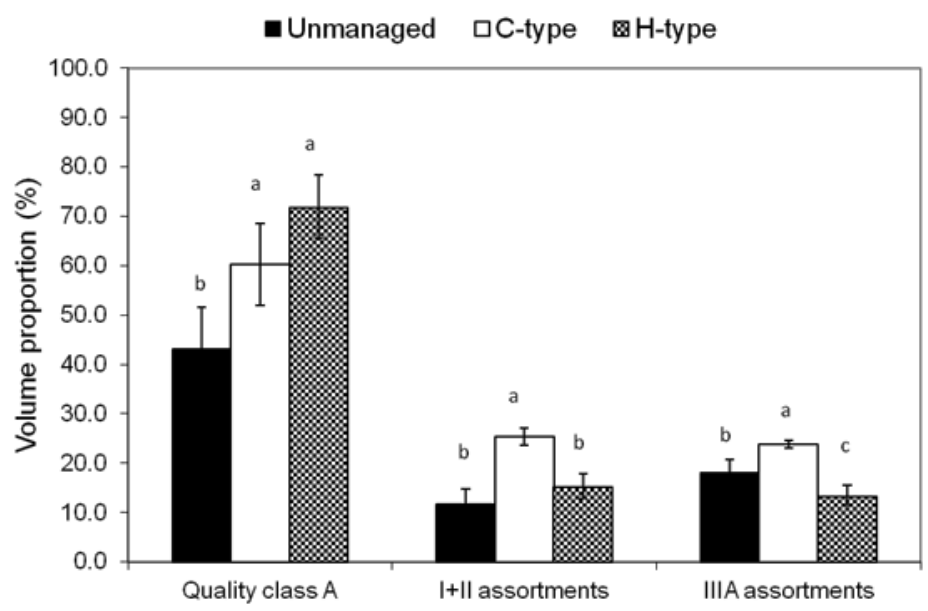

Fig. 2. Volume proportion of the highest quality (A) stems and I + II and IIIA assortments by the thinning types. Legend: C type - subplot with heavy thinning from below (C - type according to the German forest research institutes released in 1902), $\mathrm{H}$ - type - subplot with free crown thinning (thinning from above) defined by Štefančík (1974), Unmanaged - control subplot (without interventions). Note: Different letters mean statistically significant difference $(p<0.05)$ within the quality categories.

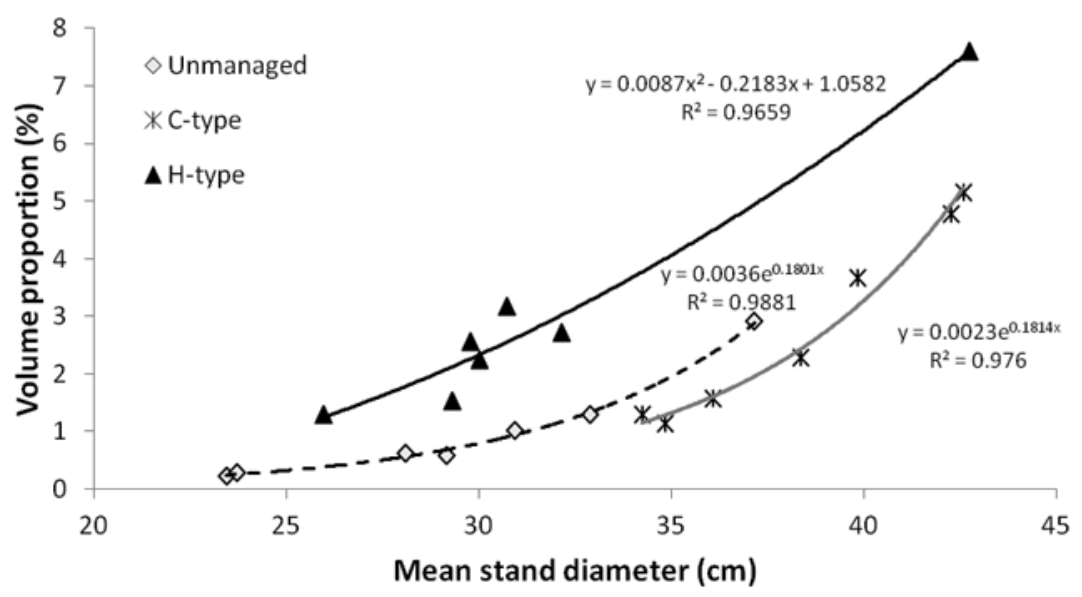

Fig. 3. Dependence of the volume proportion of best quality assortments (Class I) on the mean stand diameter $\left(d_{g}\right)$. 
In addition to stem quality, an assortment dimension (diameter) is another important feature for assigning the stems into certain assortment classes. The relationship between proportion of the best quality assortments (I. class) and the mean stand diameter largely differed between the thinning types (Fig. 3). On all subplots a modest increase of the most valuable assortments has been observed with increasing stem mean diameter. Best quality assortments was higher by $4-5 \%$ under the free crown thinning than on subplots with no tending at the same mean diameter $\left(d_{g}\right)$.

\subsection{Value production}

Beech stands under free-crown thinning reached the highest value production (per hectare) (Fig. 4a, b). Stands managed by heavy thinning from below reached less and the control subplots least value production. The value is approximate as the value production has been

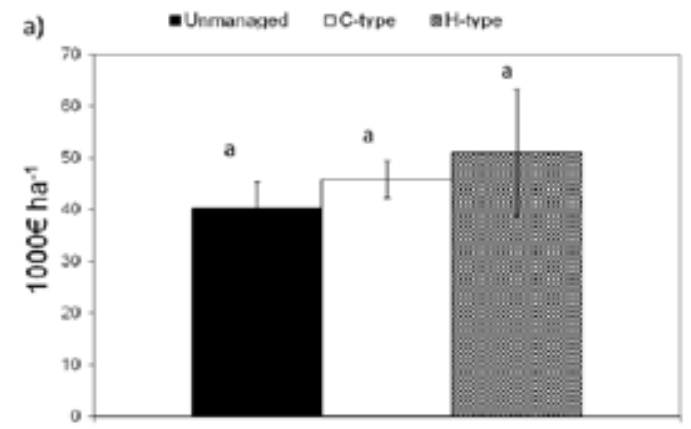

calculated for undamaged subplots, so the real value was lower.

Mean stand diameter (Fig. 5) influences the stand value production. Differences are evident above the mean diameter of $30 \mathrm{~cm}$. Stands with heavy thinning from below had in five (out of seven) plots the maximum diameters and also the highest value production (expressed by $€$ ha $^{-1}$ ). Control subplots and subplots with free crown thinning showed approximately the same values.

Subplots with free crown thinning had the highest value production (Fig. 4b), when standardized to the value per one cubic meter (ranging from 71 to $82 € \mathrm{~m}^{-3}$ ). Subplots with heavy thinning from below reached $68-76 € \mathrm{~m}^{-3}$. The lowest value production (58 $-71 € \mathrm{~m}^{-3}$ ) was found on the control subplots (without tending). Relationship between the value production (in $€ \mathrm{~m}^{-3}$ ) and the mean diameter $\left(\mathrm{d}_{\mathrm{g}}\right)$ highlighted the same trend of increasing production with the increase of mean diameter regardless to the applied thinning type (Fig. 6).

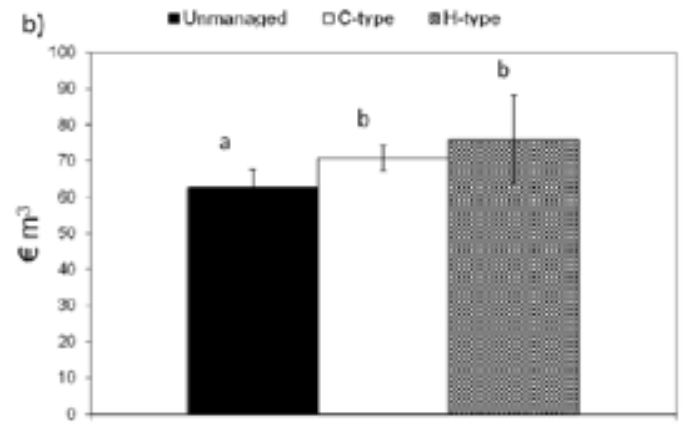

Fig. 4. Value production (a) in thousands $€$ per hectare and (b) $€$ per $\mathrm{m}^{3}$ in different thinning types. Different letters mean statistically significant difference $(\mathrm{p}<0.05)$.

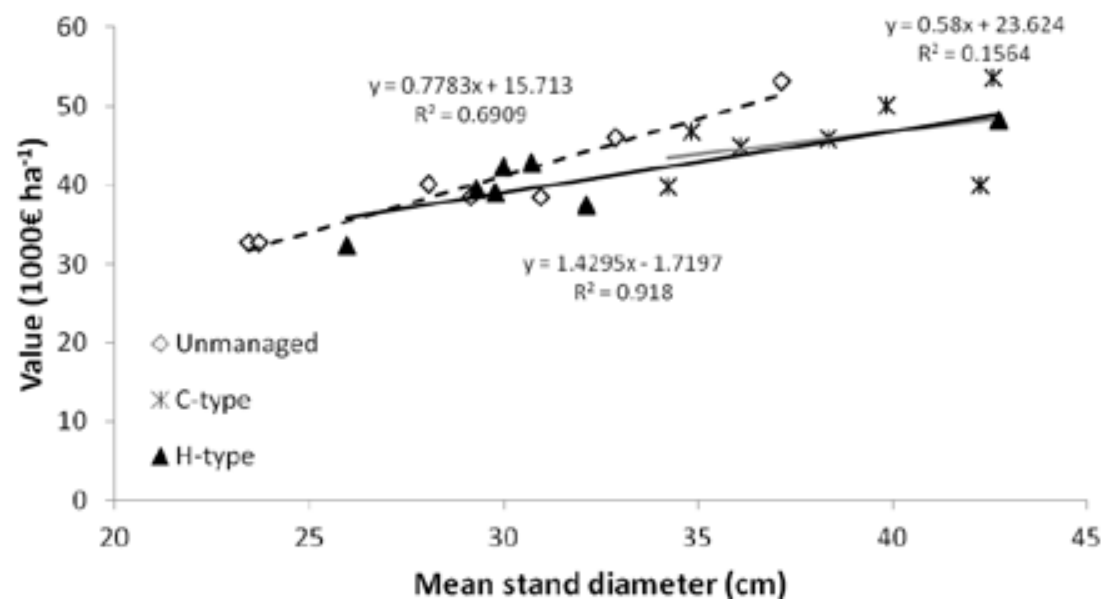

Fig. 5. Dependence of the value production (thousands $€ \mathrm{ha}^{-1}$ ) on the mean stand diameter on subplots with a different management. 


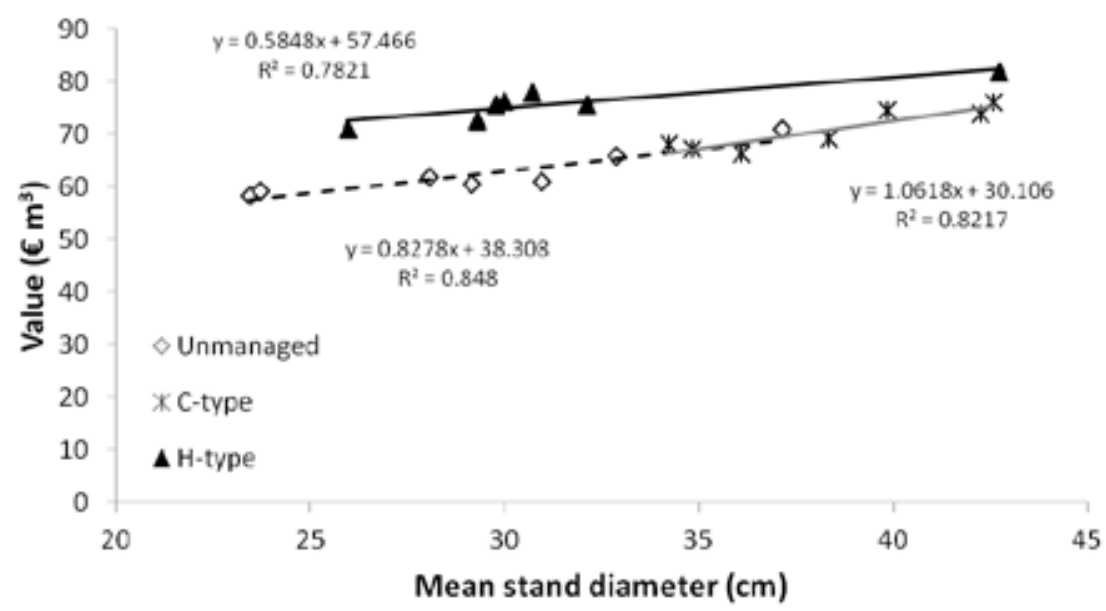

Fig. 6. Dependence of the value production $\left(€ \mathrm{~m}^{-3}\right)$ on mean stand diameter $\left(\mathrm{d}_{\mathrm{g}}\right)$ on subplots with different management.

\section{Discussion}

The highest percentage of best quality stems (class A) was reached by the free crown thinning. This thinning method is focused exclusively on individual cultivation of the highest quality trees (promising; target trees), which are selected in the stand's crown and dominant level (Štefančík 1984). These are typically the thickest trees $\left(d_{1,3} \geq 45 \mathrm{~cm}\right)$, which is necessary (in addition to qualitative characteristics) to meet the criteria of the most valuable assortments (class I). On the other hand, the highest proportion of the best quality assortments (class I + II) by volume was reached at heavy thinning from below. Contrary to thinning from above grows a stand as a whole by removing all suppressed trees and does not intervene into the crown level. Therefore it does not distinguish between individuals for their stem quality. Despite the fact that subplots with thinning from below are always characterized by highest mean diameter (Assmann 1968; Šebík \& Polák 1990; Štefančík 2015) in comparison with other methods of thinning, the proportion of the best quality stem was the highest at free crown thinning. Thus, this suggest that not only dimension of stems is important (over $45 \mathrm{~cm} \mathrm{dbh}$ ) for assorting, but also their quality characteristics and stem damage in particular. We did not directly assess the damage separately for each stem in this study, but we considered stem damage when assessing the stem quality class. However, the assortment models used in our study (Petráš \& Nociar 1991) were also based (in addition to the stem diameter and quality) on dependence on the stem damage and age. Therefore detected assortment structure can not be considered absolute, but for orientation. Presented research supports the finding, when the lowest proportion of best quality stems and assortments was found on plot Lukov (poor genetic quality of the stand) and Kalsa. It was confirmed by negative phenotypic traits (stem with deformation, greater curvature, twisted growth). As was already revealed in the past studies, a beech bark necrotic disease significantly caused later trunk rot (Štefančík \& Leontovyč 1966; Štefančík 1974) occurred on this plot and also in Konus and Jalna. On these plot, the proportion of the highest quality stems $(\mathrm{A}+\mathrm{B})$ was even higher on control subplots (without interventions) than on the subplot with free crown thinning (Štefančík 2015). This is in accordance with the other studies (Štefančík 1974; Cicák \& Mihál 2001; Cicák et al. 2003) that showed a higher rate of necrosis in managed forest stands in comparison to stands without interventions. Whereas, last interventions in the stands with thinning from below were minimal, necrosis was not reflected here. On the contrary, interventions in the stands managed by the free-crown thinning were performed even in the higher age (Štefančík 2015) to achieve the highest value increment (Assmann 1968). The occurrence of necrosis was also related to the social status of a tree, as the frequency increased with decreasing vertical position of the individuals in the stand level (Cicák \& Mihál 2002). Such approach gives those stands an advantage, because the part of the stand is removed during the first interventions, contrary to the stands with free crown thinning, where the suppressed trees frequently occur at the higher age (Štefančík 2015).

Big proportion of the best quality stems, found in stands with performed free crown thinning is related to the highest number of target trees on these subplots (Štefančík 2015). At the same time, the merchantablevolume was almost always higher in stands treated by heavy thinning from below and control subplots compared to the Štefančík's free crown thinning. This observation thus supports the suggestion to focus on the qualitative aspects of the thinning in beech stands (Kató \& Mülder 1983; Poljanec \& Kadunc 2013; Štefančík \& Bošel'a 2014) and/or on a certain number of the top quality trees (Štefančík 1974; Hein et al. 2007). In our research it was ranged from 44 to 164 individuals per hectare on subplots with heavy thinning from below and/or 68 to 184 trees on subplots with free crown thinning. However, when 
growing "mass quality", i.e. the whole stand without the focus on the highest quality (target) individuals, better results were reached in the stands managed by heavy thinning from below (Štefančík 2015), as confirmed in our study (Fig. 2).

Our results are also consistent with those provided by Hladík \& Sedmák (1996) who confirmed that the best quality was reached in the stands treated by thinning from above (reached the highest share of class A) while the lowest quality was found on control plots. The authors assumed that the value production in the stand with crown level interventions would be higher than in the stands under thinning from below. Similarly, Hein et al. (2007) showed in a 35-year experiment that the net present value of timber production in the stands with applied selection thinning was higher in comparison to the Assmann's optimal stand basal area regime. When expressed in $€ \mathrm{~m}^{-3}$, our results support these findings.

The study by Poljanec \& Kadunc (2013) showed that the quality of beech trees in Slovenia was highest at the DBH of $50-55 \mathrm{~cm}$ which is consistent with our findings, where the highest quality was observed at $\mathrm{DBH}$ of $41-50 \mathrm{~cm}$. It was also suggested that beech timber value was positively affected by high harvesting intensity (Poljanec \& Kadunc 2013), because managed stands had always better stem quality. Such conclusion confirm the importance of thinning in achieving higher quality of beech stands (Kató \& Mülder 1983; Korpel'1988; Šebík \& Polák 1990; Štefančík et al. 1996). In order to improve the quality structure of beech stands, beech would have to be grown in beech-dominated stands or clusters, and thinned at the "correct time" (Poljanec \& Kadunc 2013). Based on our experience it should be at age of 20 to 40 years in dependence on site and stand conditions.

The more valuable assortments forester manages to grow, the higher is the value production (converting timber into money). This corresponded with our observation that the highest proportion of the best quality assortments was in the forest stands managed by the free-crown thinning. At the same time, there was with the highest value production. When comparing individual localities (sites), the highest production value was found in the Zalobin, which was again related to the highest production potential of this site (largest stem diameter dimensions) compared to other plots (Bošela et al. 2016; Štefančík 2015). It should be noted that the real value production would be lower, because we did not consider damage of the assessed trees (Petráš \& Nociar 1991).

It should be highlighted that the determined production value is rather "theoretical" or "gross" because it does not take into account costs or yield during the whole observation period (over 50 years). Costs for interventions would be the highest in stands with free-crown thinning, where $10-12$ interventions were performed and the lowest (zero) on the control subplots. On the other hand, yields during the tending period were zero on the control subplot. We can speak about the "pure" produc- tion value after the cost-benefit analysis throughout the whole research period.

\section{Conclusion}

A comparison of the production value of beech stands aged between 83 - 105 years and managed in two different ways for a long-term (over 50 years) demonstrated the positive impact of tending on the stand quality. Tending of beech stands should focus on selective quality, i.e. an optimal number of individuals of the highest quality (target trees). Growing of "mass quality" through the tending focused on the whole stand, not on individual trees could lead to a higher value production, provided that there were no damage. On the other hand, such method of thinning is less favourable for the production of the most valuable assortments. After 50 years of observations, the value production was highest $\left(€ \mathrm{~m}^{-3}\right)$ in stands managed by Štefančík's free-crown thinning in comparison with heavy thinning from below and control subplots (without tending).

\section{Acknowledgement}

We thank two anonymous reviewers for valuable comments and suggestions. The study was supported by the Slovak Research and Development Agency under Contract No. APVV-0262-11, No. $A P V V$-15-0032 and No. APVV-15-0265, as well as by the project "Research and development for innovation and support of competitiveness of forestry sector-VIPLES" funded by Ministry of Agriculture and Rural Development of the Slovak Republic.

\section{References}

Assmann, E., 1968: Náuka o výnose lesa. Bratislava, Príroda, 488 p.

Bartoš, J., Souček, J., 2010: Vliv hektarového počtu na kvalitu tyčkovin buku lesního. Zprávy lesnického výzkumu, 55:33-37.

Bošela, M., Štefančík, I., Petráš, R., Vacek, S., 2016:The effects of climate warming on the growth of European beech forests depend critically on thinning strategy and site productivity. Agricultural and Forest Meteorology, 222:21-31.

Cameron, A. D., 2002: Importance of early selective thinning in the development of long-term stand stability and improved log quality: a review. Forestry, 75 : 25-35.

Cicák, A., Mihál, I., 2001: T-disease - a little investigated phenomenon of the beech (Fagus sylvatica L.) necrotic damage. Journal of Forest Science, 47: 38-41.

Cicák,A., Mihál, I., 2002: Relationship of necrotic disease of beech trunks to the sociological position of trees in the stand. Journal of Forest Science, 48:225-229. 
Cicák, A., Mihál, I., Štefančík, I., 2003. Development of necrotic disease and health condition of trees of selective quality in a systematically tended beech polestage stand. Journal of Forest Science, 49:11-18.

Ducros, E. T., Thiebaut, B., Duval, H., 1988: Variability in beech - budding, height growth and tree form. Annales des Sciences Forestieres, 45:383-398.

Ferrand, J. C., 1982: Variabilité en forêt des contraintes de croissance du hêtre (Fagus sylvatica L.). Annals of Forest Science, 39:187-218.

Gömöry, D., Paule, L., 2011: Trade-off between height growth and spring flushing in common beech (Fagus sylvatica L.). Annals of Forest Science, 68:975-984.

Gömöry, D., Comps, B., Paule, L., von Wühlisch, G., 2013: Allozyme and phenotypic variation in beech (Fagus sylvatica L.): are there any links? Plant Biosystems, 147:265-271.

Hansen, J. K, Jorgensen, B. B, Stoltze, P., 2003:Variation of quality and predicted economic returns between European beech (Fagus sylvatica L.) provenances. Silvae Genetica, 52:185-197.

Hein, S., Lenk, E., Klädtke, J., Kohnle, U., 2007: Effect of crop tree selectice thinning on beech (Fagus sylvatica L.) Allgemeine Forst- und Jagdzeitung, 178:8-20.

Hladík, M., Sedmák, R., 1996:Vplyvvýchovných zásahov na štruktúru a množstvo produkciebukového porastu (na príklade trvalej výskumnej plochy Poruba). Acta Facultatis Forestalis Zvolen, 38:127-149.

Jullien, D., Widmann, R., Loup, C., Thibaut, B., 2013: Relationship between tree morphology and growth stress in mature European beech stands. Annals of Forest Science, 70:133-142.

Kató, F., Mülder, D., 1983: Qualitative Gruppendurchforstung der Buche. Allgemeine Forst- und Jagdzeitung, 154:139-145.

Keller, R., Le Tacon, F., Timbal, J., 1976: La densité du bois de hêtre dans le nord-est de la France. Influence des caractéristiques du milieu et du type de sylviculture. Annals of Forest Science, 33:1-17.

Knoke, T., 2003: Predicting red heartwood formation in beech trees (Fagus sylvatica L.). Ecological Modelling, 169:295-312.

Knoke, T., Wenderoth, S. S., 2001: Ein Ansatz zur Beschreibumg von Wahrscheinlichkeit und Ausmaßder Farbkernbildung bei Buche (Fagus sylvatica L.). Forstwissenschaftliches Centralblatt, 120:154-172.

Korpel', Š., 1988: Dynamika rastu a vývoja bukových porastov vo fáze mladiny až žrd'oviny vplyvom pestovnej techniky. Acta Facultatis Forestalis Zvolen, 30:9-38.

Krpan, A. P. B., Prka, M., Zečic, Z., 2006: Phenomenon and characteristic of false heartwood in the beech thinnings and regenerative fellings in management unit “Bjelovarska bilogora”. Glasnik za Šumarske Pokuse, 5:529-542.
Merganič, J., Marušák, R., Merganičová, K., Stolariková, R., Tipmann, L., 2013: Relation between selected indicators of forest stand diversity and quality of timber production in young stands aged up to 40 years. Journal of Forest Science, 59:503-513.

Mlinšek, D., Bakker, A., 1990: Jugendwachstum und Holzqualität bei der Buche. Forstwissenschaftliches Centralblatt, 109:242-248.

Novotný, P., Frýdl, J., Čáp, J., 2015:Zhodnocení kvalitativních parametrů buku lesního (Fagus sylvatica L.) na sedmi provenienčních výzkumných plochách ve věku 25 let. Zprávy lesnického výzkumu, 60:14-23.

Petráš, R., Nociar, V., 1991: Sortimentačné tabulky hlavných drevín. Bratislava, Veda, 308 p.

Petráš, R., 1992: Mathematisches Modell der Sortimentstafeln für Hauptbaumarten. Lesnícky časopis, 38:323-332.

Petráš, R., Mecko, J., Bošel'a, M., 2015: Kvalita dreva a jeho hodnota $v$ zmiešaných verzus rovnorodých porastoch smreka, jedle a buka. In: Houšková, K., Černý, J. (eds.): Proceedings of Central European Silviculture. Brno, Mendelova univerzita, p. 119-130.

Poleno, Z., Vacek, S. et al., 2009: Pěstování lesů III. Praktické postupy pěstování lesů. Kostelec n. Č. lesy, Lesnická práce, $952 \mathrm{p}$.

Poljanec, A., Kadunc, A., 2013: Quality and timbervalue of European beech (Fagus sylvatica L.) trees in the Karavanke region. Croatian Journal of Forest Engineering, 34:151-165.

Richter, Ch., 2007: Holzmerkmale- Beschreibung der Merkmale-Ursachen-Vermeidung Auswirkungen auf die Verwendung des Holzes - Technologische Anpassung. DRW-Verlag Weinbrenner GmbH \& Co. $\mathrm{Kg}$, Leinfelden-Echterdingen, $82 \mathrm{p}$.

Sedmák, R., Hladík, M., 2002: Vplyv rozličného spôsobu výchovy na hodnotovú produkciu predrubného bukového porastu. Acta Facultatis Forestalis, 44:171-186.

Skovsgaard, J. P., Nordfjell, T., Sörensen, I. H., 2006: Precommercial thinning of beech (Fagus sylvatica L.): early effects of stump height on growth and natural pruning of potential crop trees. Scandinavian Journal of Forest Research, 21:380-387.

Šebík, L., 1970: Kvalita a vplyv prvých úrovňových prebierok na kvalitu predrubných bukových porastov. Zborník vedeckých prác LF VŠLD vo Zvolene, 12:31-50.

Šebík, L., Polák, L., 1990: Náuka o produkcii dreva. Bratislava, Príroda, 322 p.

Štefančík, I., 2015: Rast, štruktúra a produkcia bukových porastov s rozdielnym režimom výchovy. Zvolen, NLC, $148 \mathrm{p}$.

Štefančík, I., Bošela, M., 2014: An influence of diff erent thinning methods on qualitative wood production of European beech (Fagus sylvatica L.) on two eutrophic sites in the Western Carpathians. Journal of Forest Science, 60:406-416. 
Štefančík, L., 1974: Prebierky bukových žrd'ovín. Lesnícke štúdie č. 18, Bratislava, Príroda, 141 p.

Štefančík, L., 1984: Freie Hochdurchforstung in ungepflegten Buchenstangenhölzern. Allgemeine Forstzeitung, 95:106-110.

Štefančík, L., Leontovyč, R., 1966: O nekróze kôry miazgotoku buka na východnom Slovensku. Lesnícky časopis, 12:521-532.

Štefančík, L., Utschig, H., Pretzsch, H., 1996: Paralelné sledovanie rastu a štruktúry nezmiešaného bukového porastu na dlhodobých prebierkových výskumných plochách v Bavorsku a na Slovensku. Lesnictví - Forestry, 42:3-19.

Utschig, H., Küsters, E., 2003: Growth reactions of common beech (Fagus sylvatica L.) related to thinning -130 years observation of the thinning experiment Elmstein 20. Forstwissenschaftliches Centralblatt, 122:389-409.
Vacek, S., Hejcman, M., 2012: Natural layering, foliation, fertility and plant species composition of a Fagus sylvatica stand above the alpine timberline in the Giant (Krkonoše) Mts., Czech Republic. European Journal of Forest Research, 131:799-810.

Vacek, S., Vacek, Z., Podrazský, V., Bilek, L., Bulušek, D., Štefančík, I. et al., 2014: Structural Diversity of Autochthonous Beech Forests in Broumovske Stěny National Nature Reserve, Czech Republic. Austrian Journal of Forest Science, 131:191-214.

Vacek, Z., Vacek, S., Bílek, L., Remeš, J., Štefančík, I., 2015: Changes in horizontal structure of natural beech forests on an altitudinal gradient in the Sudetes. Dendrobiology, 73:33-45.

Vladovič, J. et al., 2014: Reakcia diverzity lesných fytocenóz na zmenu edaficko-klimatických podmienok Slovenska. Zvolen, Technická univerzita, 165 p. 